\title{
COMMENT
}

\section{CENTERING WHITENESS AND ENTRENCHING THE MYTH OF RACE-NEUTRAL ALTERNATIVES TO AFFIRMATIVE ACTION}

\author{
COURTNEY BLEDSOE ${ }^{\dagger}$
}

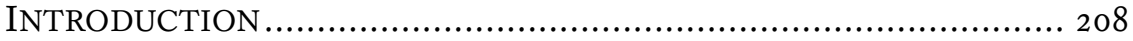

I. ON WHITE CENTERING ................................................. 212

II. EXPANDING THE PROTECTIONS OF THE FOURTEENTH AMENDMENT AND THE CIVIL Rights ACT BEYOND THE

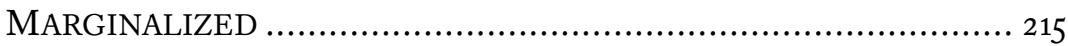

III. DEVELOPMENT OF AFFIRMATIVE ACTION JURISPRUDENCE AND The RACE-NeUtral Alternative Test AS AN OUTGROWTH OF WHITE CENTERING ...................................223

A. White Centering in Reviewing Remedial Policies in Employment ....... 224

B. White Centering in Higher Education Affirmative Action Jurisprudence. 230

IV. RaCE-NEUtral Alternatives CEnter White Interests AT THE EXPENSE OF NON-WHITE STUDENTS .......................2 234

CONCLUSION ................................................................ 238

$†$ Articles Editor, Volume 170, University of Pennsylvania Law Review; J.D. Candidate, 2021, University of Pennsylvania Law School; B.A., 2017, Williams College. I extend my deep gratitude to Professor Michael Davis for lending his wisdom and guidance during my comment writing process. Additional thanks to the editors of the University of Pennsylvania Law Review, volumes 169 and 170 , for their tireless efforts, guidance, and contributions throughout the editing process. 


\section{INTRODUCTION}

In August 1935, Lloyd Gaines, a recent Black graduate from Lincoln University-then a Black-only college operated by the University of Missouri-submitted an application for admission into the University of Missouri Law School, as Lincoln University did not have a law school at the time. ${ }^{1}$ Upon receipt of Gaines' application, the University of Missouri directed him to contact Lincoln University instead, pointing Gaines to a recently enacted state statute which promised provision of tuition for any law school in an adjacent state "[p]ending the full development of the Lincoln university."2 In other words, because the school only offered tuition funds to Black students attending out-of-state law schools, the University of Missouri would not accept Black law school applicants and Gaines could only apply to an out-of-state law school. While Gaines was otherwise qualified to attend the University of Missouri School of Law, he was refused admission on the grounds of his race. ${ }^{3}$ Gaines promptly brought an action against the University of Missouri, arguing that this denial violated the Fourteenth Amendment and demanding admission into the law school. ${ }^{4}$ The Supreme Court found that the state of Missouri was compelled to procure a legal education for Gaines within the state, rather than providing tuition for an outof-state school, and determined that Gaines was entitled admission to the University of Missouri School of Law if no other legal education was available in the state. ${ }^{5}$ Gaines' story of exclusion is but a vignette of the myriad struggles Black students and other students of color have faced while attempting to gain entry into institutions of higher education in the United States. 6

1 Missouri ex rel. Gaines v. Canada, 305 U.S. 337, 342(1938).

2 Id. at 342 .

$3 \mathrm{Id}$. at 343 .

4 Id. at 342 .

$5 \mathrm{Id}$. at 352 . Just under two years after this momentous victory, Gaines disappeared and was never to be heard from or seen again-he ultimately never enrolled in the University of Missouri. To this day, Gaines' disappearance baffles historians and civil rights activists, but his legacy remains alive and well; students at the University of Missouri recently implored the school to erect a statue of Gaines next to the University of Missouri School of Law. Kathryn Palmer, Legacy of Missing Lloyd Gaines, 1928 Supreme Court Plaintiff, Still Haunts Higher Education, KBIA (Dec. 12, 2018), https://www.kbia.org/post/legacy-missing-lloyd-gaines-1938-supreme-court-plaintiff-still-hauntshigher-education\#stream/o [https://perma.cc/SXE5-YRV2].

6 See generally Sweatt v. Painter, 339 U.S. 629, 629 (1950) (discussing other educational opportunities provided to Black students in light of their exclusion from the University of Texas Law School); McLaurin v. Okla. State Regents for Higher Educ., 339 U.S. 637, 639-40 (1950) (considering a Black Univ. of Okla. student who was accepted to the university on the condition that he remain segregated from white students); Sipuel v. Board of Regents of University of Okl., 332 U.S. 631, 63132 (1948) (discussing the case of petitioner Sipuel, a Black student who was rejected from the University of Oklahoma School of Law on the basis of her race despite being otherwise qualified). 
While policy-based mechanisms of excluding students of color from higher education have dissolved, students hailing from these groups continue to face systemic barriers to colleges and universities across the United States. A study by the U.S. Department of Education found that, compared to white students, a disproportionate number of Black students enroll in community colleges or for-profit institutions (which usually entail higher tuition rates and lower graduation rates) than four-year universities. ${ }^{7}$ Additionally, white adults are twice as likely to hold at least a bachelor's degree than Hispanic adults, ${ }^{8}$ and only $19 \%$ of college-aged Indigenous students are enrolled in college as compared to $41 \%$ of the overall U.S. population. ${ }^{9}$ In the wake of the Civil Rights Movement, many universities attempted to address the severe lack of diversity on their campuses by initiating affirmative action policiesmechanisms for increasing the enrollment of students hailing from diverse and historically disadvantaged backgrounds. 10 These measures took on various forms, such as "opportunity programs" through which universities evaluated applicants devoid of concrete admission requirements; targeted recruitment efforts at local high schools; the consideration of race during application review; and the creation "points" systems through which applicants hailing from certain minority backgrounds would be granted an admissions "boost."11

Decades later, Abigail Fisher, a white applicant to the University of Texas at Austin, filed a lawsuit against the school alleging that its affirmative action

7 See Walter R. Allen, Channel McLewis, Chantal Jones, \& Daniel Harris, From Bakke to Fisher: African American Students in U.S. Higher Education Over Forty Years, 4 THE RuSSELL SAGE FOUND. J. SOC. SCIS. 41, 43 (2018) ("[M]ore than 50 percent of all African American college students are enrolled in community colleges, and only 40 percent of whites attend these institutions. African American students are also overrepresented in for-profit institutions, where students pay higher tuition, more frequently default on student loans, and graduate less often.").

8 Richard Fry, Jesse Bennet \& Amanda Barroso, Racial and Ethnic Gaps in the U.S. Persist on Key Demographic Indicators, PEW RSCH. CTR. (Jan. 12, 2021), https://www.pewresearch.org/interactives/racial-and-ethnic-gaps-in-the-u-s-persist-on-keydemographic-indicators [https://perma.cc/3WY8-X9V6].

9 Factsheets: Native American Students, POSTSECONDARY NAT'L POL'Y INST. (Nov. 17, 2020) https://pnpi.org/native-american-students [https://perma.cc/5A7B-GAPB].

10 Current scholarship remains split on what factors ultimately motivated schools to launch affirmative action policies. Some question whether disruptive student action at certain elite schools such as Harvard, Yale, and Princeton spearheaded affirmative action policies, while others have theorized that the much larger urban unrest in cities such as Newark and Detroit, as well as the Watts riots, pushed schools to action. Lisa M. Stulberg \& Anthony S. Chen, The Origins of RaceConscious Affirmative Action in Undergraduate Admissions: A Comparative Analysis of Institutional Change in Higher Education, 87 SOCIO. EDUC. 36, 37 (2013).

11 See, e.g., id. at 41-42 (highlighting examples of targeted recruitment and opportunity programs, as well as admissions generally considering race in a student's application at universities like Cornell, Swarthmore, and Dartmouth); Gratz v. Bollinger, 539 U.S. 244, 244 (2003) ("The current guidelines use a selection method under which every applicant from an underrepresented racial or ethnic minority group is automatically awarded 20 points of the 100 needed to guarantee admission."). 
policy unlawfully discriminated against Fisher because she was white. ${ }^{12}$ While Fisher's academic credentials were unremarkable-indeed, the school admitted only forty-seven applicants with grades and test scores lower than Fisher's, forty-two of them white-Fisher argued that the school rejected her because its admissions process considered applicants' race. ${ }^{13}$ Although the Supreme Court ultimately ruled in the school's favor, ${ }^{14}$ Fisher's allegations embodied a significant shift in claims regarding discrimination within university admission. In the years following Gaines' lawsuit, white plaintiffs began pushing back against schools' attempts to rectify abysmal levels of campus diversity through race-based affirmative action policies. Students who did not stand to benefit from affirmative action began to seek legal relief against schools implementing such policies, alleging that race-based affirmative action violated federal constitutional rights to equal protection..$^{15}$

In addressing these disputes, courts have required schools to first consider race-neutral alternatives to race-based admissions policies to achieve their diversity goals. ${ }^{16}$ In recent years, the standard has evolved into a requirement that no workable race-neutral alternative exist for a school to maintain a racebased affirmative action program. ${ }^{17}$ Such a requirement appears inconsistent with the overall goals of race-based affirmative action plans-how can a school

12 See Fisher v. Univ. of Tex. at Austin, 570 U.S. 297, 297 (2013) (discussing Abigail Fisher's allegations that the University's affirmative action policy constituted unlawful racial discrimination).

13 Nikole Hannah-Jones, What Abigail Fisher's Affirmative Action Case Was Really About, PROPUBLICA (June 23, 2016, 12:28 PM), https:/www.propublica.org/article/a-colorblindconstitution-what-abigail-fishers-affirmative-action-case-is-r [https://perma.cc/9PKR- 5 FYA].

14 Fisher v. Univ. of Tex. at Austin, 136 S. Ct. 2198, 2215 (2016).

15 See, e.g., DeFunis v. Odegaard, 507 P.2d 1169, 1175 (Wash. 1973) ("[T]he Admissions Committee followed certain procedures which are the crux of plaintiff's claimed denial of equal protection of the laws."); Regents of Univ. of Cal. v. Bakke, 438 U.S. 265, 277 (1978) ("[The plaintiff] alleged that the Medical School's special admissions program operated to exclude him from the school on the basis of his race, in violation of his rights under the Equal Protection Clause of the Fourteenth Amendment ...."); Gratz, 539 U.S. at 244 ("Petitioners filed this class action alleging the University's use of racial preferences in undergraduate admissions violated the Equal Protection Clause of the Fourteenth Amendment . . ..") Grutter v. Bollinger, 539 U.S. 306, 306 (2003) (finding against the plaintiff and holding the University of Michigan Law School violated plaintiff's fourteenth amendment rights to equal protection through their admissions policies); Fisher, 570 U.S. 297, 297 (2013); Fisher, 136 S. Ct. at 2198-99; Students for Fair Admissions, Inc. v. President and Fellows of Harvard Coll., 397 F. Supp. 3d 126, 131 (D. Mass. 2019) ("Plaintiff . . . alleges that Defendant ... discriminates against Asian American applicants in the undergraduate admissions process to Harvard College in violation of Title VI of the Civil Rights Act of 1964.").

16 Grutter, 539 U.S. at 309, 339 ("Narrow tailoring does not require exhaustion of every conceivable race-neutral alternative ... [it] does, however, require serious, good faith consideration of workable race-neutral alternatives that will achieve the diversity the university seeks.").

17 Fisher, 570 U.S. at 312 ("The reviewing court must ultimately be satisfied that no workable race-neutral alternatives would produce the educational benefits of diversity."); Students for Fair Admissions, 397 F. Supp. at 177 ("Harvard may consider race to achieve diversity only if there is no workable race-neutral alternative to the consideration of race to ensure a sufficiently diverse class."). 
which hopes to increase racial diversity achieve such diversity through nonracial means?

In this Comment, I argue that the current jurisprudence on affirmative action in institutions of higher education rests on the continued centering of whiteness, ultimately creating a doctrine which attempts to achieve a "painless" solution to racial injustice through prioritizing the need to ensure no race-neutral alternatives exist. Ultimately, this "painless" cure places a substantial roadblock in the path to true racial equity in higher education. By white centering, I refer to the ways in which whiteness is prioritized and acts as the focal point for any discussion of diversity and racial equity-and, in this instance, affirmative action-with non-white interests fashioned as a lesser priority. 18

Part I discusses the meaning of white centering and provide a brief overview of how white centering has manifested as non-white individuals have struggled for equality throughout United States history. Part II analyzes how courts have determined to whom the Fourteenth Amendment and the Civil Rights Act of 1964 applies, finding that courts' expansion of these protections beyond Black individuals paved a pathway for white individuals to invoke these safeguards in affirmative action efforts. Part III explores the development of affirmative action jurisprudence and the race-neutral alternative test. There, I conclude that the requirement that schools have no workable race-neutral alternative before turning to race-based affirmative action is the result of the Court's centering of white demands and interests over the past 50 years. By focusing its analysis on the potential harms that race-based affirmative action policies could bring upon white individuals, the Court established a trend of prioritizing white interests while deprioritizing the needs of Black Americans and other people of color.19 In Part IV, I assess

18 The phrase "white centering" has gained traction in recent years and has been used increasingly beginning in the summer of 2020 to describe the tendency to focus on the wishes of white individuals - and whiteness as both an idea and ideal-even in discussions about racial equity. See Sarah Mayorga-Gallo, The White-Centering Logic of Diversity Ideology, 63 AM. BEHAV. SCIENTIST 1789, 1789-90 (2019) (using the phrase "white centering" to refer to the prioritization of "white people's desires and feelings"). The phrase "white centering" has shown up in a variety of conversations about racial equity, ranging from discussions about racism in religious spaces to antiracism social campaigns. See Brandi Miller, Reclaiming My Theology: From White Supremacy: White Centering w. Rev. Dr. Brenda Salter McNeil, APPLE PODCASTS (Aug. 20, 2020), https://podcasts.apple.com/ie/podcast/from-white-supremacy-white-centering-w-rev-dr-

brenda/id1516576461?i=1000488719859; Nicole Cardoza, Stop White Centering, ANTI-RACISM DAILY (Feb. 5, 2021) https://www.antiracismdaily.com/archives/stop-white-centering-anti-racism-daily [https://perma.cc/DBM4-ME $\mathrm{DE}_{3}$.

19 I use the term "race-based affirmative action" rather than "race-conscious affirmative action" in consideration of the fact that many proxy-based affirmative action plans such as class-based affirmative action remain conscious of the ways in which socioeconomic status correlates with race in the United States. 
the viability of so-called race-neutral alternatives to affirmative action initiatives. There is substantial evidence that such race-neutral alternatives are ineffective at achieving diversity, raising the question of why courts insist on requiring schools to first ensure that no workable race-neutral alternatives exist. Here, I argue that this insistence on race-neutral alternatives is a product of the Court's tendency to protect the interests of whiteness above all else, especially with any attempts to remedy racial discrimination. Finally, I argue that courts should acknowledge the legacy of white centering in affirmative action jurisprudence and work to change this by refocusing their analysis on the benefits that affirmative action will provide to Black and other non-white minority students. Only through this way will courts achieve a standard of review that allows schools to more freely pursue their goals of campus diversity.

\section{ON WHITE CENTERING}

The term "white centering" entered anti-racist discourse with relative force in the summer of 2020, when the United States faced a racial reckoning following the murders of George Floyd and Breonna Taylor by police officers in Minneapolis and Louisville, respectively. ${ }^{20}$ While the phrase rose to mainstream usage in 2020, it has been used in previous years to address frequent tendencies of both individuals and institutions to prioritize white feelings and interests over those of people of color. ${ }^{21}$ In response to the protests following George Floyd's death, many companies announced efforts to combat racism in their workplaces, some of which eventually came under fire for disingenuity. ${ }^{22}$ Somewhere during this movement, the phrase "white

20 See generally Evan Hill, Ainara Tiefenthäler, Christiaan Triebert, Drew Jordan, Haley Willis $\&$ Robin Stein ., How George Floyd Was Killed in Police Custody, THE N.Y. TIMES (last updated April 20, 2021), https://www.nytimes.com/2020/05/31/us/george-floyd-investigation.html [https://perma.cc/LL8B-EYWY] (detailing the events leading up to and following George Floyd's murder); Amina Elahi, 'Sleeping While Black': Louisville Police Kill Unarmed Black Woman, NPR (May 13, 2020, 6:33 PM), https://www.npr.org/2020/05/13/855705278/sleeping-while-black-louisville-policekill-unarmed-black-woman [https://perma.cc/Q868-MZK9] (detailing the events leading up to and following Breonna Taylor's murder); Radhika Chalasani, George Floyd Protests Aren't Just Happening in Big Cities, ABC NEWS (June 20, 2020, 11:29 AM), https://abcnews.go.com/US/article/george-floydprotests-happening-big-cities/story?id=71327256 [https://perma.cc/6C76-69MU] (highlighting smaller U.S. cities where racial justice protests unfolded in 2020).

21 See Mayorga-Gallo, supra note 18 at 1790 (discussing, in 2019, the ways in which discussions of diversity have been subsumed by "white people's desires and feelings"); Jemimah L. Young, Marquita D. Foster \& Dorothy Hines, Even Cinderella is White: (Re)Centering Black Girls' Voices as Literacies of Resistance, 107 ENG. J. 102, 102 (2018) (detailing the ways in which Black girls must be re-centered in fiction after centuries of literature upholding whiteness as paramount).

22 For examples of these commitments and ensuing backlash, see The Estée Lauder Companies Commits to Racial Equity, THE ESTÉE LAUDER COMPANIES INC. (June 10, 2020), https://www.elcompanies.com/en/news-and-media/newsroom/company-features/2020/elc-commits- 
centering" gained widespread traction as a means of envisioning how the concept of whiteness shapes social structures and ideals. The phrase has been used to deconstruct entrenched racist ideology in Christianity, ${ }^{23}$ to discuss the operation of white privilege in society, ${ }^{24}$ and to attack the underlying assumptions and frameworks of conversations around diversity. 25 According to British author Layla Saad, "white centering is a natural consequence of white supremacy. If you unconsciously believe you are superior, then you will unconsciously believe that your worldview is the one that is superior, normal, right, and that it deserves to be at the center." 26 Ultimately, in white centering, white individuals position their own interests as paramount while relegating the needs of Black, Indigenous, and other people of color as a secondary consideration.

Although the phrase "white centering" has entered common discourse only recently, scholars and authors have discussed societal structures which clearly exemplify a tendency for white individuals to prioritize their own desires and interests. Kimberlé Crenshaw, in analyzing the ways in which mainstream feminism has historically excluded Black women, argued that "discrimination against a white female is . . the standard sex discrimination claim; claims that diverge from this standard appear to present some sort of hybrid claim." 27 Crenshaw highlights the tendency for society to use whiteness as the central framework through which to understand sex discrimination and womanhood, relegating Black women to a mere afterthought. ${ }^{28}$ Further, Crenshaw highlights the fact that white women at the 1851 Women's Rights Conference in Ohio - the site of Sojourner Truth's famous "Ain't I a Woman?" speech—objected to Truth's participation, fearing that she would shift the conversation from women's suffrage to Black

to-racial-equity [https://perma.cc/2XB8-5 $\mathrm{HP}_{4}$ ]; Gillian Friedman, Here's What Companies Are promising to Do to Fight Racism, N.Y. Times (Aug. 23, 2020), https://www.nytimes.com/article/companies-racism-george-floyd-protests.html [https://perma.cc/NK7W-F9R3]; Emma Hinchliffe, Exclusive: Ex-Glossier Employees Describe a Company That Failed to Support Black Workers-Even as it Donated \$1 Million to Racial Justice Causes, FORTUNE (Aug. 18, 2020, 7:45 AM), https://fortune.com/2020/08/18/glossier-black-workers-donationsupport-black-lives-ceo-emily-weiss/ [https://perma.cc/PKP8-NHWM].

23 See Miller, supra note 18.

24 Austin Channing Brown, White Privilege Weariness (Part II), ROLL CALL WITH AUSTIN CHANNING BROWN (Apr. 1, 2014), http://austinchanning.com/blog/tag/centering [https://perma.cc/WGH8-F6SZ] ("I have been unable to stop thinking about how much healing [Black people] need for ourselves, another reason why we must decenter whiteness.").

25 Mayorga-Gallo, supra note 18, at 1789-90.

26 Layla F. SaAd, Me and White Supremacy: Combat Racism, Change the WORLD, AND BECOME A GOOD ANCESTOR 136 (2020).

27 Kimberlé Crenshaw, Demarginalizing the Intersection of Race and Sex: A Black Feminist Critique of Antidiscrimination Doctrine, Feminist Theory and Antiracist Politics, 1989 U. CHI. LEGAL F. 139, 145 (1989).

$28 I d$. at 152 . 
emancipation. ${ }^{29}$ The tendency of white women to position their own whiteness as the sole framework for understanding feminism provides one example of white centering at work even in the antebellum period.

During the Black American struggle for Civil Rights in the mid-19oos, white centering manifested in the form of white Americans agreeing to integration efforts only when such efforts aligned with their own interests. Derrick Bell, a professor at Harvard Law School instrumental in the development of critical race theory, asserted that this prioritization of white interests appeared even in the assessment of anti-segregation claims. ${ }^{30}$ According to Bell, the Court's mid-19oos shift from apprehensiveness about integration to increasing attentiveness to the harms of segregation was at least partially attributable to the ways in which integration would help "win the hearts and minds" of people from developing countries in the struggle against Communism. ${ }^{31}$ Additionally, Bell argued, southern white Americans began to realize that integration was necessary for advancing southern society from a "rural, plantation society to the sunbelt with all its potential and profit . . .."32

Through this tendency to center whiteness, white individuals have often imagined themselves as innocent victims of discrimination and, as such, proactively worked to protect their own interests at the expense of marginalized groups. Critical race scholar Cheryl Harris has argued that there is a "property interest in whiteness [which] has skewed the concept of affirmative action by focusing on the sin or innocence of individual white claimants with vested rights as competitors of Blacks whose rights are provisional and contingent, rather than on the broader questions of distribution of benefits and burdens." 33 Harris' theory is perhaps best reflected in Shelley v. Kraemer, wherein white St. Louis residents attempted to restrict local homeownership to white buyers and Black prospective buyers were unable to obtain property interest in what white people previously owned. 34

29 Id. at 153

30 Derrick A., Bell, Comment, Jr., Brown v., Board of Education and the Interest-Convergence Dilemma, 93 HARV. L. REV. 518, 524-25 (1980).

$31 \mathrm{Id}$. at 524 .

$32 \mathrm{Id}$. at 525 .

33 Cheryl I. Harris, Whiteness as Property, 106 HARV. L. REV. 1707, 1780 (1993).

34 The text of the attempted prohibition is as follows:

$[\mathrm{H}]$ ereafter no part of said property or any portion thereof shall be, for said term of Fifty-years, occupied by any person not of the Caucasian race, it being intended hereby to restrict the use of said property for said period of time against the occupancy as owners or tenants of any portion of said property for resident or other purpose by people of the Negro or Mongolian Race.

Shelley v. Kraemer, 334 U.S. 1, 4-5 (1948). 
The positioning of white individuals as innocent and equally susceptible to racial discrimination appears in the reasoning in Ricci v. DeStefano, where the Supreme Court maintained that a city could not discard test results which suggested a disparate impact on Black firefighters because such action would constitute unlawful discrimination against the mostly white testers. ${ }^{35}$ Harris and Professor Kimberly West-Faulcon argued that the Court's ultimate finding of unlawful discrimination against the white firefighters in Ricci "whitened" discrimination by moving towards "converting efforts to rectify racial inequality into white racial injury." 36 The Court in Ricci thus shifted the discrimination analysis to focus chiefly on potential injuries sustained by white individuals, maintaining that not only could white people suffer from discrimination in the same manner as people of color, but that remedies for racial inequity constituted discrimination against white people. ${ }^{37}$

White centering has taken shape over the years in affirmative action jurisprudence in multiple ways. First, courts center whiteness by focusing on the alleged harms that ostensibly befall white plaintiffs and similarly situated students should affirmative action be permitted to continue in higher education. Second, courts center whiteness by engaging in discourse which frames whiteness as innocence, thus positioning white plaintiffs as unreasonably and unjustly harmed by an institution that has decided to play favorites. In the rest of this Comment, I will discuss the ways in which both anti-discrimination legislation and affirmative action jurisprudence have evolved in a way that inherently centers white desires and fears, as well as how courts' emphasis on race-neutral alternatives further prioritizes white interests.

\section{EXPANDING THE PROTECTIONS OF THE FouRTEENTH AMENDMENT AND THE CIVIL RIGHTS ACT BEYOND THE \\ MARGINALIZED}

Over the past several decades, numerous lawsuits have arisen alleging that race-based affirmative action policies at colleges and universities constitute unlawful racial discrimination, with the plaintiffs usually identifying as white. ${ }^{38}$ Moreover, some such lawsuits have involved white plaintiffs who had

35 Ricci v. DeStefano, 557 U.S. 557, 593 (2009) (highlighting that testers had studied for months at "considerable personal and financial expense," thus making the injury to them "all the more severe.").

36 Cheryl I. Harris \& Kimberly West-Faulcon, Reading Ricci: Whitening Discrimination, Racing Test Fairness, 58 UCLA L. REV. 73, 81 (2010).

$37 \mathrm{Id}$.

38 See, e.g., Fisher v. Univ. of Tex. at Austin, 570 U.S. 297, 297 (2013) (assessing allegations that the University of Texas at Austin's affirmative action policy unlawfully discriminated against the white plaintiff); Grutter v. Bollinger, 539 U.S. 306, 306 (2003) (discussing a white plaintiff's 
average or below-average academic credentials, calling into question whether they would have been admitted regardless of the school's affirmative action policy. ${ }^{39}$ This backlash is consistent with the ways in which equal protection laws and affirmative action jurisprudence have evolved over the past two centuries. Beginning with the development of the Fourteenth Amendment, lawmakers and courts endeavored to protect white interests by assuring fellow white Americans that any legislation would not unduly interfere with their existing privileges.

In the years following the Civil War, certain lawmakers sought to provide protections for newly emancipated African Americans and thus proposed what would later be known as the Freedmen's Bureau Act. ${ }^{40}$ The legislation would create a Bureau which would provide food, land, and other necessities to Southern freedmen, as well as white Civil War "refugees." 41 The 1866 bill went through several iterations, with legislators in both the House and the Senate taking issue with the ways in which the bill ostensibly favored Black Americans over white Southerners.42 One Senator objected that the bill would make African Americans "superior" to their white counterparts by

claims that the University of Michigan Law School's affirmative action plan unlawfully discriminated against the plaintiff because of her race) Gratz v. Bollinger, 539 U.S. 244, 244 (2003) (discussing a white plaintiff's claims that the University of Michigan's College of Literature, Science, and the Arts implemented an affirmative action policy that unlawfully discriminated against the plaintiff because of their race). Following her 2016 defeat in Supreme Court, Abigail Fisher became known to many on the Internet as "Becky with the Bad Grades," referring to Fisher's apparent willingness to blame her otherwise commonplace rejection on minority students. See Abby Jackson, People Are Tweeting a Modified Beyoncé Lyric to Mock the Woman at the Center of the Supreme Court's Case on Affirmative Action, BUSINESS INSIDER (June 27, 2016, 6:18 PM), https://www.businessinsider.com/what-becky-withthe-bad-grades-means-2016-6. [https://perma.cc/6W6H-G $3 \mathrm{QH}$ ]. While the plaintiffs in Students for Fair Admissions Inc. v. President $\mathcal{E}$ Fellows of Harvard College allege that Harvard's affirmative action policy discriminates against Asian American applicants, some point out that this case and a later investigation into Yale's admissions practices seeks to "pit marginalized students against each other, using Asian Americans as the conduit" to ultimately uphold white privilege. Kimmy Yam, Don't Use Asians to Maintain White Privilege, Critics Say After DOJ Letter to Yale, NBC NEWS (Aug. 14, 2020, 5:33 PM), https://www.nbcnews.com/news/asian-america/don-t-use-asians-maintain-whiteprivilege-critics-say-after-n1236843 [https://perma.cc/GAH4-475 T].

39 See Hannah-Jones, supra note 13 (stating that, in Fisher, neither Fisher nor her attorney mentioned that only around fifty students with lower scores than Fisher's were admitted and that forty-two of those students were white); ); Regents of Univ. of Cal. v. Bakke, 438 U.S. 265,277 n.7 (1978) (noting that plaintiff Bakke's science and overall grade point averages were below those of average admits during the first cycle in which he was rejected).

40 Freedmen's Bureau Acts of 1865 and 1866, U.S. Senate, https://www.senate.gov/artandhistory/history/common/generic/FreedmensBureau.htm [https://perma.cc/5KYG-KWD4] (last visited May 11, 2021).

$41 \mathrm{Id}$.

42 Eric Schnapper, Affirmative Action and the Legislative History of the Fourteenth Amendment, 71 VA. L. REV. 753, 763 (1985) ("Objections to the 1866 [Freedmen's Bureau] bill were similar to those advanced earlier, but the arguments against special treatment for blacks were more fully developed."). 
"giv[ing] them favors that the poor white boy in the North cannot get." 43 Despite such staunch opposition, Congress reached an agreement on the bill's necessity and constitutionality and passed the law-only for President Andrew Johnson to veto the bill, unwilling to provide social support for Black Americans when white Americans were not afforded the same assistance. ${ }^{44}$

In the wake of the veto, some congressmen seemed to view the Fourteenth Amendment as providing a Constitutional foothold for the protections afforded in the vetoed Act. ${ }^{45}$ For many legislators, the Fourteenth Amendment had the advantage of providing broader protections than the Freedmen's Bureau could ever seek to achieve, and some viewed the Amendment as simply another means of achieving the goals set forth in the Freedmen's Bureau discussions. ${ }^{46}$ Thus, at its inception, the Fourteenth Amendment was in many ways a mechanism of directly redressing the harms of slavery and lasting discrimination against African Americans.

After the Fourteenth Amendment's ratification, the Supreme Court discussed the interests at play in the Amendment's creation in the Slaughterhouse Cases. There, the plaintiffs challenged the constitutionality of a New Orleans regulation mandating the closure of all slaughterhouses and stock landings in the city to create a single "grand slaughter-house." 47 The plaintiffs, who worked as butchers in New Orleans, argued that this statute violated the Thirteenth and Fourteenth Amendments in that they mandated involuntary servitude and deprived them of their "life, liberty, or property, without due process of law." 48 In evaluating these claims, the Supreme Court noted that

$[\mathrm{O}] \mathrm{n}$ the most casual examination of the language of these amendments, no one can fail to be impressed with the one pervading purpose found in them all, lying at the foundation of each, and without which none of them would have been even suggested; we mean the freedom of the slave race, the security and firm establishment of that freedom, and the protection of the newly-made freeman and citizen

\footnotetext{
43 Cong. GlOBE, 39th Cong., 1st Sess. 401 (1866) (quoting Senator MacDougall).

44 Schnapper, supra note 42 , at 769.

$45 \mathrm{Id}$. at 785-86 (detailing how supporters believed the Act and amendment to be "complementary" and how Congress may have adopted the Fourteenth Amendment "in part to provide a constitutional basis for the Freedmen's Bureau Act.").

$46 \mathrm{Id}$. at 785 (explaining supporters' beliefs that Congress, aware of the "racial limitations in the Freedmen's Bureau programs" could not have passed the Fourteenth Amendment with the understanding that it would "forbid the adoption of such remedies by itself or the states").

47 Slaughterhouse Cases, 83 U.S. 36, 40, 43 (1872).

$48 \mathrm{Id}$. at $43-44$.
} 
from the oppressions of those who had formerly exercised unlimited dominion over him. 49

The Court, while acknowledging that the protections of the Reconstruction Amendments were not explicitly limited to Black citizens, underscored that an accurate reading of these amendments must consider that the "pervading spirit of them all" was the desire to remedy the evils of chattel slavery in the United States. ${ }^{50}$

Within a matter of years, the Court began to broaden this relatively narrow understanding of the Fourteenth Amendment given rampant discrimination against Chinese Americans. In 188o, the city of San Francisco passed an ordinance requiring that any individual running a laundromat not built of brick or stone must obtain approval from the board of supervisors; failure to comply would result in substantial fines or imprisonment for a maximum of six months. ${ }^{51}$ Yick Wo, a Chinese national residing in San Francisco, had been operating a laundromat in the same wooden building for over twenty years. ${ }^{52}$ Although local authorities repeatedly found Wo's business to be up to code, he and 150 other Chinese nationals and Chinese Americans were arrested for failure to obtain approval for operating wooden laundromats.53 However, eighty non-Chinese individuals who ran laundromats under similar conditions were allowed to continue their businesses freely. ${ }^{54}$ Wo and other Chinese laundromat owners had repeatedly requested approval from the board of supervisors, only to have their applications denied, while similarly situated non-Chinese laundromat owners' applications were approved (with only one exception). 55 The Court determined that this disparate treatment violated the federal Constitution, given that the regulation

divides the [laundromat] owners or occupiers into two classes ... by an arbitrary line, on one side of which are those who are permitted to pursue their industry by the mere will and consent of the supervisors, and on the other those from whom that consent is withheld, at their mere will and pleasure. ${ }^{56}$

Justice Matthews, writing the opinion of the Court, opined that the protections of the Fourteenth Amendment "are universal in their application,

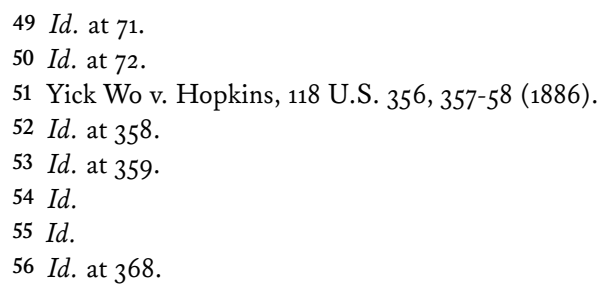


to all persons within the territorial jurisdiction, without regard to any differences of race, of color, or of nationality; and the equal protection of the laws is a pledge of the protection of equal laws." 57

At first blush, the Court's reading of the Fourteenth Amendment appears inherently racialized. Justice Matthews confirmed that the Fourteenth Amendment applied to individuals of all races residing in the United States. However, this interpretation effectively stripped the Amendment of its racial contours by emphasizing the law's universality. ${ }^{58}$ Where Justice Miller in the Slaughterhouse Cases looked to the historical context of the Fourteenth Amendment and accordingly limited its reading to the harmful vestiges of slavery, Justice Matthews evaluated the law apart from its original framing.

Yick Wo carved out important rights for people of color beyond African Americans and is consistent with the underlying aims of the Fourteenth Amendment-protecting individuals from marginalized ethnic and racial groups from white American oppression. This holding was particularly salient in its provision of substantive rights to Chinese Americans when the United States began restricting their ability to live and work domestically.59 At the same time, the Court's reasoning provided a foothold for white Americans to solidify their own privileges and hinder change which could benefit people of color. By interpreting the Fourteenth Amendment as one that affords universal protections within the United States rather than cabining its protections to marginalized groups, the Supreme Court-either wittingly or unwittingly-subtly paved the path for future courts to apply the law to programs which would remediate the legacy of the very racial oppression Chinese Americans and other people of color challenged. After Yick Wo, the Fourteenth Amendment applied to all racial groups, and the Court thus had clear precedent to use the Amendment as a roadblock to policies which remedied racial marginalization at the expense of white individuals.

The Supreme Court adopted this more expansive approach to the Fourteenth Amendment over the next century when reviewing racist and marginalizing statutes. In Hirabayashi v. United States, the Court considered the constitutionality of a curfew imposed on Japanese Americans and

57 Id. at 369.

58 See generally Thomas W. Joo, Yick Wo Re-Visited: Nonblack Nonwhites and Fourteenth Amendment History, U. ILL. L. REV. 1427, 1427-28 (2008) (discussing the expansion of the protections of the Fourteenth Amendment to people of color beyond Black individuals).

59 See Act of May 6, 1882, ch. 126, 22 Stat. 58, 59 (repealed 1943) ("[T]he coming of Chinese laborers to the United States [will] be, and the same is hereby, suspended; and during such suspension it shall not be lawful for any Chinese laborer to come, or, having so come after the expiration of said ninety days, to remain within the United States."); The Chinese Exclusion Case, 130 U.S. 581,582 (1889) (discussing the case of Chae Chan Ping, who briefly left the United States prior to the passage of the Chinese Exclusion Act only to be barred from reentry following the Act's passage). 
Japanese nationals residing in the United States during the Second World War.60 Although the Court was tasked with evaluating Hirabayashi's claims under the Fifth Amendment, it nevertheless considered the implications such a policy might have for the doctrine of equal protection. ${ }^{61}$ Despite concluding that wartime interests overrode any concerns regarding racial discrimination, Chief Justice Stone opined that "distinctions between citizens solely because of their ancestry are by their very nature odious to a free people whose institutions are founded upon the doctrine of equality. For that reason, legislative classification or discrimination based on race alone has often been held to be a denial of equal protection." 62

More than two decades later, the Court in Loving v. Virginia, striking down an anti-miscegenation law, borrowed this exact language from Hirabayashi to underscore that the Virginia law barring interracial marriage ran afoul of the Equal Protection Clause.63 While, unlike in Loving, the Court in Hirabayashi ultimately upheld the racially invidious statute, both cases, in adopting the aforementioned language, underscored that the Fourteenth Amendment is not limited in scope to descendants of enslaved African peoples. Instead, the protections of the Fourteenth Amendment could be claimed by individuals of any race. ${ }^{64}$

These three cases served as the foundation of modern affirmative action jurisprudence by shaping the Court's interpretation of the Fourteenth Amendment. The Court commendably eschewed the Slaughterhouse Court's narrow interpretation of the Fourteenth Amendment to expand its protections to Asian-Americans and interracial marriages, providing substantive rights to members of marginalized groups who hoped to enjoy the rights previously granted exclusively to white Americans. However, the Court's expansion of these rights ironically paved the path to an interpretation of the Fourteenth Amendment which would ultimately prop up the interests of the white majority and stymie attempts to gain further equity for marginalized groups through affirmative action policies. By asserting that the Fourteenth Amendment's protections extended to all individuals, the Court provided a shield which white individuals could invoke

60 See generally, Hirabayashi v. United States, 320 U.S. 81, 81 (1943).

$61 \mathrm{Id}$. at 100 .

$62 I d$.

63388 U.S. $1,11(1967)$.

64 See id. at 12 ("To deny this fundamental freedom [of marriage] on so unsupportable a basis as the racial classifications embodied in these statutes, classifications so subversive of the principle of equality at the heart of the Fourteenth Amendment, is surely to deprive all the State's citizens of liberty without due process of law."); Hirabayashi, 320 U.S. at 100 ("Distinctions between citizens solely because of their ancestry are by their very nature odious to a free people whose institutions are founded upon the doctrine of equality. For that reason, legislative classification or discrimination based on race alone has often been held to be a denial of equal protection."). 
against affirmative action policies which would provide more equitable opportunities for marginalized groups at the expense of white Americans.

In the wake of these cases, the Court even interpreted the Civil Rights Act of 1964 in a way that reflected the concept that classifications negatively impacting any racial group were invidious and unlawful. The Civil Rights Act is substantively distinct from the Fourteenth Amendment in a variety of ways, such as its explicit prohibition of discrimination on the basis of "race, color, religion, sex, or natural origin," but the underlying principles of equal protection pervade the Act's language. 65 The years leading up to the legislation's enactment were punctuated by severe and pervasive violence against Black Americans who sought equal treatment under the law-civil rights leader Medgar Evers was killed on his doorstep, lunch counter sit-ins spread across the country, and young students joined in on peaceful protests that turned violent against them. ${ }^{66}$ Even though the Civil Rights Act was created in response to the strengthening movement for African American civil rights in the $1960 \mathrm{~s},{ }^{67}$ the Court began interpreting this legislation in a way that protected not only African Americans and other historically marginalized groups, but also white Americans who felt targeted by affirmative action policies in schools and workplaces. ${ }^{68}$ Indeed, President Kennedy hoped that the Civil Rights Act would ensure that "every American [can] enjoy the privileges of being American, without regard to his race or his color." 69

To this end, one decade after Loving, the Court built upon its previous conclusion that the Fourteenth Amendment protected all citizens by invoking Title VII of the Civil Rights Act to block an affirmative action policy which would protect Black individuals from termination at the expense of their white coworkers.70 In McDonald v. Santa Fe Trail Transportation Company, a white union member sued the Santa Fe Trail Transportation Company for his

65 Civil Rights Act of 1964, Pub. L. No. 88-352, 78 Stat. 251, 254 (describing the duties of the Commission on Civil Rights as, among other things, "study[ing] and collect[ing] information concerning legal developments constituting a denial of equal protection of the laws under the Constitution because of race, color, religion or natural origin or in the administration of justice").

66 Paulette Brown, The Civil Rights Act of 1964, 92 WASH. U. L. REV. 527, 527 (2014).

67 See H.R. REP. NO. 914, pt. 2, at 21 ("The transition from all-Negro to integrated schools is at best a difficult problem of adjustment for teachers and students alike . . . It is clear then that the Congress must enact legislation empowering the Federal government to disseminate information concerning desegregation plans, problems, and possible solutions ....").

68 See McDonald v. Santa Fe Trail Transp. Co., 427 U.S. 273, 279 (1976) (holding that Title VII applied to white employees in the same way it applied to Black employees in an employment discrimination lawsuit).

69 President John F. Kennedy, Report to the American People on Civil Rights (June 11, 1964) (transcript available at https://www.jfklibrary.org/learn/about-jfk/historic-speeches/televisedaddress-to-the-nation-on-civil-rights) [https://perma.cc/X243-SPH9] (emphasis added).

70 McDonald, 427 US. at 273-83 (1976). 
termination for "misappropriating [the company's] property" while a Black employee who faced similar charges retained his employment. ${ }^{71}$ There, Justice Marshall asserted that "Title VII prohibits racial discrimination against the white petitioners in this case upon the same standards as would be applicable were they Negroes and Jackson white."72

In reaching his conclusion, Justice Marshall drew upon the holding of McDonnell Douglas Corp. v. Green, where the plaintiff alleged he was wrongfully denied re-employment because he was Black. ${ }^{73}$ Building on the McDonnell Douglas Court's assertion that an employer may not use an employee's unlawful conduct as pretext for racial discrimination, Justice Marshall asserted that "The [Civil Rights] Act prohibits all racial discrimination in employment, without exception for any group of particular employees ...."74 Additionally, Justice Marshall explicitly rejected the argument that the Civil Rights Act, given its history, should only be extended to discrimination against Black Americans, noting that while the immediate context and motivation for the creation of the Civil Rights Act was the protection of Black Americans' civil rights, the Act's drafters adopted "broad language" with the intent to include individuals of all backgroundsincluding white Americans. ${ }^{75}$ In arriving at this conclusion, Justice Marshall referenced a Senate floor debate regarding the purpose of the Civil Rights Act of 1866; there, Senator Trumbull responded to Senator Davis' concerns that the bill would protect only Black Americans at the expense of white Americans' privileges:

Sir, this bill applies to white men as well as black men. It declares that all persons in the United States shall be entitled to the same civil rights, the right to the fruit of their own labor, the right to make contracts, the right to buy and sell, and enjoy liberty and happiness; and that is abominable and iniquitous and unconstitutional! Could anything be more monstrous or more abominable than for a member of the Senate to rise in his place and denounce with such epithets as these a bill, the only object of which is to secure equal rights to all the citizens of the country, a bill that protects a white man just as much as a black man?76

$71 \mathrm{Id}$. at $275-76$.

$72 \mathrm{Id}$. at $28 \mathrm{o}$.

73 Id. at 281-82. See generally McDonnell Douglas Corp. v. Green, 411 U.S. 792, 804 (1973) ("Petitioner may justifiably refuse to rehire one who was engaged in unlawful, disruptive acts against it, but only if this criterion is applied alike to members of all races.").

74 McDonald, 427 U.S. at 283 .

$75 \mathrm{Id}$. at 289 .

76 Id. at 290; CONG. GLOBE, 39th Cong., 1st Sess. 599 (1866). 
This exchange between Senators Trumbull and Davis exemplifies the ways in which even the white drafters of remedial legislation such as the Civil Rights Act insisted on safeguarding white privilege and interests even if the law's original goal was the provision of substantive rights to a historically marginalized racial group. Senator Davis' objections to the bill clearly demonstrate a willingness of white individuals to accept protections for Black people-but only if lawmakers considered the status and privileges of white Americans as though both white and Black interests were equally susceptible to unlawful or suspect discrimination.

This desire to include white individuals under the Civil Rights Act's protective umbrella evidences an unwillingness to safeguard the rights of marginalized racial and ethnic groups without considering the desires of white individuals. In the years following the McDonald decision, the Court embodied the very tendency to center white desires and interests reflected in the aforementioned Senate debate. This resulted in the adoption of a standard for reviewing affirmative action claims which created additional burdens for schools looking to achieve greater diversity in the wake of discrimination against Black individuals and other people of color in higher education.

\section{DEVELOPMENT OF AFFIRMATIVE ACTION JURISPRUDENCE AND THE RACE-NEUTRAL AlterNATIVE TEST AS AN OUTGROWTH OF WHITE CENTERING}

As entities in the United States ranging from universities to employers sought to contend with the legacy of slavery, Jim Crow, and disparate treatment of Black Americans and other people of color, the Court refined its interpretation of both the Fourteenth Amendment and the Civil Rights Act in a way that nevertheless protected white interests. In the years after the enactment of the Civil Rights Act of 1964, employers enacted affirmative action policies which sought to shield Black employees from adverse employment action, particularly given that many industries had clear disparities in the number of Black and white employees.77 Subsequently, institutions of higher education looked to provide some means of addressing the lack of Black and other people of color on their campuses through affirmative action admissions policies of varying natures. Unsurprisingly,

77 See generally United Steelworkers of Am. v. Weber, 443 U.S. 193, 198 (1979) (discussing an aluminum plant's affirmative action plan setting aside recent openings for Black Americans); Wygant v. Jackson Bd. of Educ., 476 U.S. 267, 272 (1986) (discussing a school district's policy of firing only white teachers to "remedy societal discrimination by providing 'role models' for minority schoolchildren"); Fullilove v. Klutznick, 448 U.S. 448, 454 (1980) (discussing an affirmative action program aimed at providing financial support for minority groups which were historically economically disadvantaged). 
white plaintiffs alleged that such policies violated the Constitution or the Civil Rights Act.

In addressing these lawsuits, the Court developed a jurisprudence that held equality, rather than equity, as paramount. Just as Black individuals could not be treated differently because of their race, the Court reasoned, white employees and college applicants could not be discriminated against because of their race. Over the years, the Court established two major principles for addressing affirmative action cases. First, a court must apply strict judicial scrutiny to any affirmative action policy that considers race. Second, any entity defending a race-based affirmative action policy must be able to show that they first considered race-neutral alternatives to achieve similar levels of diversity. In this section, I show both developments track the Court's tendency to protect white interests by entrenching white "innocence" in racial wrongdoing, emphasizing that white individuals do not deserve disparate treatment when the goal is remedying past and ongoing racial harm.

\section{A. White Centering in Reviewing Remedial Policies in Employment}

Much of today's affirmative action jurisprudence developed in response to the Supreme Court's holdings in cases regarding employers who sought to address questions of racial inequity within their workplaces. In the wake of the Civil Rights movement and the resulting Civil Rights Act of 1964, some public and private sector employers adopted policies with a goal of remedying historical racial discrimination. ${ }^{78}$ Predictably, white employees alleged that such policies violated the Fourteenth Amendment and Title VII of the Civil Rights Act. It was through these employment discrimination cases that the Supreme Court developed the language and precedent to address affirmative action plans within the context of colleges and universities. By focusing its analysis on the potential detriments these affirmative action plans may have on white individuals, the Supreme Court laid the foundation for its "raceneutral alternative" test within the context of academic affirmative action plans.

In United Steelworkers of America v. Weber, manufacturer Kaiser Aluminum \& Chemical Corporation ("Kaiser") and the United Steelworkers of America created an affirmative action plan in an attempt to remedy the legacy of

78 See generally United Steelworkers, 443 U.S. 193, 198 (1979) (addressing an aluminum plant's affirmative action plan which set aside $50 \%$ of recent openings in employment training programs to rectify historical racial imbalances in the company's craftwork department); Fullilove, 448 U.S. 448, 454 (1980) (discussing an affirmative action program aimed at providing financial support for minority groups which were historically economically disadvantaged); Wygant, 476 U.S. 267,272 (1986) (discussing a school district's policy of firing only white teachers to "remedy societal discrimination by providing 'role models' for minority schoolchildren"). 
discrimination in its historically white craftwork department. ${ }^{79}$ As a result of racially discriminatory hiring and employment practices, Black employees comprised only $1.83 \%$ of the skilled craftworkers at the plant, despite the fact that the surrounding area was $39 \%$ Black. 80 To address this disparity, Kaiser set aside, for the plant's Black employees, $50 \%$ of openings in its craftwork training programs. ${ }^{81}$ In response to this initiative, white employees filed a class action against Kaiser, alleging that the reservation of slots for Black employees resulted in unfair preferential treatment of junior Black employees and discrimination against more senior white employees. ${ }^{82}$ Ultimately, the Supreme Court held that "Title VII's prohibition in $\S \S 703(a)$ and (d) against racial discrimination does not condemn all private, voluntary, race-conscious affirmative action plans." 83 Here, the Court gave the green light to the corporate affirmative action program given that its goal was to "break down old patterns of racial segregation and hierarchy." 84 This holding appeared relatively promising for affirmative action efforts given that it enabled private employers to self-evaluate their hiring and promotion practices and make changes to promote racial representation and equity. Moreover, the Court, in reaching its conclusion, appeared unwilling to read Title VII in a way that blocked attempts to address "the plight of the Negro in our economy." 85

The Court later modified its approach to affirmative action in Fullilove v. Klutznick. There, the Court upheld an affirmative action policy but asserted that such policies warranted heightened judicial scrutiny. The legislation at issue in Fullilove, the Public Works Employment Act, included a "minority business enterprise" ("MBE") provision requiring that grants could not be made to any public works project unless at least $10 \%$ of each grant would go towards MBEs. 86 That same year, several firms working in construction and HVAC filed a complaint against the Secretary of Commerce and the State and City of New York, alleging that the MBE provision unlawfully discriminated against non-minority businesses under the Fourteenth Amendment and the Due Process Clause. 87

In reviewing the statute, the Court underscored that any legislation adopting racial classifications must be closely scrutinized, regardless of

79 United Steelworkers, 443 U.S. at 197-98.

80 Id. at $198-99$.

$81 \mathrm{Id}$. at 198.

82 Id. at 199

$83 \mathrm{Id}$. at 208.

$84 \mathrm{Id}$.

85 Id. at 202 (quoting Senator Humphrey's remarks in 110 CONG. REC. 6548 (1964)).

86 Fullilove, 448 U.S. at $453-54$.

$87 \mathrm{Id}$. at 455 . 
intent. ${ }^{88}$ The Court maintained that "by its objective of remedying the historical impairment of access, the MBE provision can have the effect of awarding some contracts to MBE's which otherwise might be awarded to other businesses, who may themselves be innocent of any prior discriminatory actions." ${ }^{9}$ Weighing the benign intent of the statute against the incidental detriments the regulation would pose to non-minority businesses, Justice Burger, writing for the majority, concluded that "[w]hen effectuating a limited and properly tailored remedy to cure the effects of prior discrimination, such 'a sharing of the burden' by innocent parties is not impermissible." 90 While the majority ultimately maintained that such affirmative action plans were constitutionally permissible, the language of white "innocence" framed both the majority's analysis and that of future courts assessing affirmative action plans. By portraying white individuals as "innocent" within the context of racial discrimination, the Court presented a situation in which blameless members of the majority are forced to bear the burden of legislation seeking to remedy historical racial discrimination.

The language of innocence ultimately removed white individuals from the racist and oppressive past of the United States and underscored that the affirmative action plans might be unfair to nonminority individuals, though nonetheless necessary. Thus, while the Court ultimately upheld the statutory provision, its language regarding the innocence of white individuals provided a framework for future courts' discussion of whether the burden affirmative action plans would place on white individuals could be justified.

The Court continued to view affirmative action plans through the lens of whiteness several years later in Wygant v. Jackson Board of Education. There, the Court considered a public school's addition, through a collective bargaining agreement, of a provision protecting certain minority employees against layoffs. 91 The provision maintained that the percentage of minority employees laid off could not exceed the percentage of minority individuals employed by the Board at the time of the layoff.92 Additionally, the provision required that the most senior employees would be kept on the payroll.93 Following layoffs during two academic years wherein relatively junior teachers remained on the Board payroll while more senior nonminority

$88 \mathrm{Id}$. at 491 ("Any preference based on racial or ethnic criteria must necessarily receive a most searching examination to make sure that it does not conflict with constitutional guarantees.").

89 Id. at 484 (emphasis added).

$90 \mathrm{Id}$.

91 Wygant v. Jackson Bd. of Educ., 476 U.S. 267, 270 (1986).

92 Id. at $270-71$.

$93 \mathrm{Id}$. ("In the event that it becomes necessary to reduce the number of teachers through layoff from employment by the Board, teachers with the most seniority in the district shall be retained (..."). 
teachers were laid off, the terminated nonminority teachers sued, alleging that the protective provision violated the Equal Protection Clause and Title VII. 94

Justice Powell, writing for the majority, underscored that plans which use racial classifications for remedial purposes receive the same level of judicial scrutiny as those which use classifications to discriminate against historically marginalized groups. ${ }^{95}$ The Board must therefore, the Court emphasized, present both a "compelling governmental interest" justifying the plan and demonstrate that the plan was "narrowly tailored" to achieve this goal.96 Rejecting the Board's proposed "role model theory" (wherein maintaining certain numbers of minority teachers would work to "alleviate the effects of societal discrimination"), Justice Powell asserted that, absent a finding of historical racial discrimination within the Board's employment practices, it could not be authorized to use racial classifications. ${ }^{97}$ To that end, Justice Powell maintained that

[s]ocietal discrimination, without more, is too amorphous a basis for imposing a racially classified remedy ... [A]s the basis for imposing discriminatory legal remedies that work against innocent people, societal discrimination is insufficient and over expansive. In the absence of particularized findings, a court could uphold remedies that are ageless in their reach into the past, and timeless in their ability to affect the future. 98

Justice Powell emphasized that while there were certain burdens that may acceptably be placed on "innocent" individuals, termination of "innocent" employees was simply untenable. ${ }^{99}$ By emphasizing the innocence of the displaced white employees (and white Americans more broadly), the majority framed the Board's layoff provision as a remedial measure that was unfairly severe against innocent employees who ostensibly had no personal responsibility for the societal woes the Board sought to remedy.

$94 \mathrm{Id}$. at 272.

95 Id. at 273 (citing Loving, 388 U.S. at 11) ("This Court has 'consistently repudiated '[d]istinctions between citizens solely because of their ancestry' as being 'odious to a free people whose institutions are founded upon the doctrine of equality ....'”).

96 Id. at 274.

$97 \mathrm{Id}$. ("Rather, the Court has insisted upon some showing of prior discrimination by the government unit involved before allowing limited use of racial classifications in order to remedy such discrimination.").

$98 \mathrm{Id}$. at 276.

99 Id. at 282-83 ("Though hiring goals may burden some [sic] innocent individuals, they simply do not impose the same kind of injury that layoffs impose. Denial of a future employment opportunity is not as intrusive as loss of an existing job."). 
Although Justice Powell referred to the "innocence" of the displaced white employees, at no point in the opinion did he provide a framework for understanding why the petitioners were presumed innocent. In penning his opinion, Justice Powell did not acknowledge the ways in which the white employees may have themselves participated in discriminatory behavior or benefitted from systemic discrimination, racism, or marginalization both within the school district and without. ${ }^{100}$ Indeed, this language presents a view in which racism is comprised of intentional, deliberate, and discrete acts-where no overt or explicit malice can be detected, there is no racism. In addition, Justice Powell, rather than considering at length the ways in which such a policy would remedy historical discrimination and racial inequity, focused his analysis on the injuries the white petitioners sustained and emphasized that there simply was not enough evidence demonstrating that this harm was warranted. In this, the Court in Wygant drew a line in the sand regarding what was too injurious to "innocent" white individuals when employers considered remedial measures; the Court stopped far short of allowing employers to protect Black individuals from layoffs on the basis of societal discrimination. In other words, the Wygant court rejected the Board's layoff provision because it was too painful to its white former employees.

Both Fullilove and Wygant referred to the premise that race-based affirmative action remedies would impose unthinkable burdens upon innocent parties. However, both cases failed to present any evidence regarding this presumed innocence. This failing reveals the Court's propensity to view racial justice through the lens of whiteness-the Court presumed all white individuals are innocent within the context of racial discrimination and therefore should not be subjected to disadvantageous racial classifications for benign, remedial purposes. By positing the innocence of white individuals and framing affirmative action as something that is detrimental to white individuals (rather than something that remediates ongoing harm to people of color), the Court perpetuated a system in which affirmative action may only go forward if the burden on white individuals is minimal and, if there's to be any burden on white people, it must be absolutely necessary for racial equity.

100 Although the following sources were published in the years following the Wygant decision, they nevertheless discuss the ways in which whiteness has, over time, afforded privileges inaccessible to those who do not identify (or were not identified by others) as white. See, e.g., Jerome McCrystal Culp, Jr., To the Bone: Race and White Privilege, 83 MINN. L. REV. 1637, 1639 (1999) (discussing the ways in which white privilege operates to exclude people of color from legal academia); George J. Sefa Dei, Leeno Luke Karumanchery \& Nisha Karumanchery-Luik, Chapter Four: White Power, White Privilege, 244 COUNTERPOINTS 81, 84 (2004) ("Whiteness is defined by a privilege that goes unseen: an invisibility that in many ways places our oppressor outside the racial sphere, vested with a power and social advantage which they themselves need not consider-'That's just the way it is.'”). 
While a presumption of innocence is a fundamental tenet of U.S. criminal law (and rightfully so), ${ }^{101}$ the application of the "innocent until proven guilty" principle to white individuals when considering the topic of racial discrimination is less appropriate and even harmful to people of color. Black individuals and other people of color have asserted that racism is not a question of "good and bad" people-racism is instead about the ways in which white people either advertently or inadvertently uphold systems of oppression and marginalization. ${ }^{102}$ White people may be less likely to speak out against injustices experienced by their non-white counterparts ${ }^{103}$ and may even perpetuate systemic inequities despite being considered "nice" people within their communities.104 White individuals benefit from years of entrenched systemic racism - for example, Black families have a more difficult time amassing intergenerational wealth than their white counterparts, ${ }^{105}$ and Black and Hispanic drivers are more likely to be searched at traffic stops than white motorists. 106

This is all to say that an assumption that white individuals are "innocent" victims who would be unfairly penalized by race-based affirmative action programs dangerously oversimplifies the ways in which whiteness has been privileged at the expense of other groups' social, economic, and political

101 To be clear, the phrase "innocent until proven guilty" is not black letter law in the United States; however, it has been entrenched as a commonly understood idea in cases such as Coffin $v$. United States and In re Winship. Coffin v. United States, 156 U.S. 432, 453 (1895) ("The principle that there is a presumption of innocence in favor of the accused is the undoubted law, axiomatic and elementary, and its enforcement lies at the foundation of the administration of our criminal law."); In re Winship, 397 U.S. 358, 363 (1970) ("The reasonable-doubt standard ... provides concrete substance for the presumption of innocence ....").

102 Reni Eddo-Lodge, Why I'm No Longer Talking to White People About Race, THE GUARDIAN (May 30, 2017, 12:30 AM), https://www.theguardian.com/world/2017/may/30/why-im-no-longertalking-to-white-people-about-race [https://perma.cc/WTV8-2MUY].

103 See Christina Capatides, White Silence on Social Media: Why Not Saying Anything is Actually Saying a Lot, CBS NEWS (June 3, 2020, 8:37 PM), https://www.cbsnews.com/news/white-silenceon-social-media-why-not-saying-anything-is-actually-saying-a-lot/ (noting that white individuals' unwillingness to speak out against racial injustice harms Black people).

104 See Terry Gross, Podcast Examines How "Nice White Parents" Become Obstacles in Integrated Schools, NPR (October 12, 2020, 1:48 PM), https://www.npr.org/2020/10/12/922092481/podcastexamines-how-nice-white-parents-become-obstacles-in-integrated-schools [https://perma.cc/ $\mathrm{M}_{3} \mathrm{JX}-{ }_{5} \mathrm{UU}_{3}$ ] (discussing when white families gentrified a neighborhood in New York City and pushed their children to attend "diverse schools," effectively leading to a racially segregated school system that prioritized white students' education).

105 Emily Badger, Claire Cain Miller, Adam Pearce \& Kevin Quealy, Extensive Data Shows Punishing Reach of Racism for Black Boys, N.Y. Times (Mar. 19, 2018), https://www.nytimes.com/interactive/2018/03/19/upshot/race-class-white-and-black-men.html [https://perma.cc/G 3 VJ-VUZD] (last visited August 26, 2021) ("Most white boys raised in wealthy families will stay rich or upper middle class as adults, but black boys raised in similarly rich households will not.").
106 Findings,
THE STAN. OPEN
POLICING
ProjeCt, https://openpolicing.stanford.edu/findings/ [https://perma.cc/6FXC-9KZJ]. 
wellbeing. Such an assumption diverts attention from, and effectively negates, the lived experiences of marginalized communities by asserting that white individuals are equally susceptible to discrimination - all while white individuals have upheld the very systems of oppression that people of color fight against. In other words, the Court's framing of whiteness as innocence stymies meaningful change by claiming that, at a minimum, that whiteness has been used as a gatekeeping mechanism and a means of disenfranchising other groups for years.

As we will see, however, the Court did not cease its tendency to center whiteness in the above case law. The Court adopted the white-centering framework from the above case law as schools sought to diversify their admitted classes, placing higher burdens on institutions to protect white interests.

\section{B. White Centering in Higher Education Affirmative Action Jurisprudence}

After the Court in Wygant, Fullilove, and United Steelworkers assessed the validity of remedial measures within the context of employment, the Court turned to the growing trend of colleges and universities implementing affirmative action to increase diversity on their campuses. The aforementioned cases, however, provided a framework within which the Court understood affirmative action in higher education: it could not unduly burden white individuals, who were themselves "innocent" of the legacy of racial discrimination which schools sought to address. By leaning on the groundwork laid in Wygant, Fullilove, and United Steelworkers, the Court formulated a framework wherein white innocence and interests were paramount: the race-neutral alternative test.

The Court showcased its propensity to center whiteness and operate on a presumption of white innocence in Regents of University of California $v$. Bakke. ${ }^{107}$ Alan Bakke, a white applicant to the University of California, Davis Medical School, sued the school after he was denied admission twice, alleging that the school's affirmative action plan violated the Equal Protection Clause and Title VI of the Civil Rights Act. ${ }^{108}$ Specifically, Bakke claimed that the school's "special program" which reserved sixteen seats for minority students and compared minority applicants against each other rather than the larger pool of applicants constituted unlawful racial discrimination. ${ }^{109}$ Bakke applied

107 Regents of Univ. of Cal. v. Bakke, 438 U.S. 265, 265 (1978).

108 Id. at $276-78$.

$109 \mathrm{Id}$. at 278. It is worth noting several characteristics of Bakke's two applications to UC Davis Medical School. First, Bakke submitted his first application late in the cycle, at which point the school only admitted applicants with an evaluation "benchmark" score of at least 470 , unless the applicant hailed from a racial minority group. $I d$. at 276 . After this rejection, Bakke sent a letter to 
to the school twice; the first time, his application was submitted late with lower than average credentials.110 In affirming the holding of the Court of Appeals, Justice Powell reemphasized that strict scrutiny is warranted for any racial classification-even if the classification disadvantages groups which have not been historically targeted or disadvantaged.111 To this point, Justice Powell emphasized that the Supreme Court has never "held that discreteness and insularity constitute necessary preconditions to a holding that a particular classification is invidious." 112

Thus, Justice Powell expanded the language provided in United States $v$. Carolene Products Company by emphasizing that strict scrutiny does not depend on whether the negatively impacted group has been historically marginalized or disadvantaged; instead policies negatively impacting white individuals are subject to the same "searching judicial inquiry." 113 Moreover, Justice Powell opined that the Fourteenth Amendment could not reasonably apply to only Black individuals, given that since the enactment of the Fourteenth Amendment, a number of additional ethnic and religious minorities joined American society, including Japanese-, Mexican-, Irish-, and Chinese-Americans.114 After providing an expansionist view of the Equal Protection Clause which included white Americans, Justice Powell argued that schools cannot ask white individuals such as Bakke "to suffer otherwise impermissible burdens in order to enhance the societal standing of their ethnic groups." 115 Throughout the opinion, the Court focused primarily on the exclusion of white students 116 as opposed to the potential benefits that the school's affirmative action plan would have on Black and other non-white students. Indeed, the Court spent approximately four pages discussing the ways in which affirmative action policies unfairly disadvantaged white

the Associate Dean and Chairman of the school's admission program, complaining that the special admissions program was an unfair racial quota. Id. While in the subsequent admissions cycle, Bakke's application was given a score of 549 out of 600 , the same Associate Dean Bakke contacted the previous admissions cycle acted as Bakke's faculty interviewer and expressed clear concerns about Bakke's candidacy. $I d$. at 277. Bakke was once again rejected without placement on the waitlist. $I d$.

$110 \mathrm{Id}$. at 276 .

$111 \mathrm{Id}$. at $289-90$ ("The guarantee of equal protection cannot mean one thing when applied to one individual and something else when applied to a person of another color. If both are not accorded the same protection, then it is not equal.").

$112 \mathrm{Id}$. at 290.

113 United States v. Carolene Products Co., 304 U.S. 144, 154 n.4 (1938) ("[W]hether prejudice against discrete and insular minorities may be a special condition, which tends seriously to curtail the operation of those political processes ordinarily to be relied upon to protect minorities, and which may call for a correspondingly more searching judicial inquiry.").

114 Bakke, 438 U.S. at 292-93.

$115 \mathrm{Id}$. at 298.

116 See id. at 305 (emphasizing that schools should implement affirmative action plans "without excluding individuals belonging to any other group from enjoyment of the relevant opportunity"). 
individuals, ${ }^{117}$ but swiftly discussed the benefits of such policies in approximately one page. ${ }^{118}$ In its review of Bakke's claims, the Court hardly considered the benefits of this system while underscoring the detrimental effects on Bakke and similarly situated students. By centering the desires and expectations of white students such as Bakke, the Court positioned affirmative action plans like that implemented by UC Davis Medical School as an undue burden on innocent individuals, regardless of how commendable the goal might be.

The Court further focused its analysis on the perceived hardships affirmative action plans would present to white individuals in Grutter v. Bollinger by introducing an additional test for considering whether a school could adopt a race-conscious admissions policy: the "race-neutral alternative" test.119 In Grutter, the white plaintiff alleged that the University of Michigan Law School's affirmative action plan, which sought to enroll a "critical mass' of [underrepresented] minority students" by considering race in applicant evaluations, violated the Fourteenth Amendment and Title VI of the Civil Rights Act. ${ }^{120}$ While the Court disagreed with the plaintiff's argument that the plan was not narrowly tailored to the school's diversity goals because raceneutral alternatives existed, the Court underscored that "narrow tailoring . . . require[s] serious, good faith consideration of workable race-neutral alternatives that will achieve the diversity the university seeks." ${ }^{21}$ The Court reiterated Wygant's statement that narrow tailoring requires consideration of "lawful alternative and less restrictive means" prior to launching race-based affirmative action plans. ${ }^{122}$

The Grutter Court thereby clearly increased the requirement for entities looking to initiate affirmative action plans-the standard was no longer simply that "less restrictive" methods should be considered, but that those alternative methods must be race-neutral. And while the Grutter court ultimately allowed the University of Michigan Law School to move forward in its race-conscious affirmative action plan, the Court nevertheless laid out the framework for protecting white interests by requiring schools to first consider race-neutral alternatives.

The Grutter Court's added "race-neutral alternative" requirement persisted in the following years, with the Supreme Court applying the standard to Abigail Fisher's Equal Protection claims in Fisher v. University of Texas, requiring schools to first ensure that disrupting white interests was

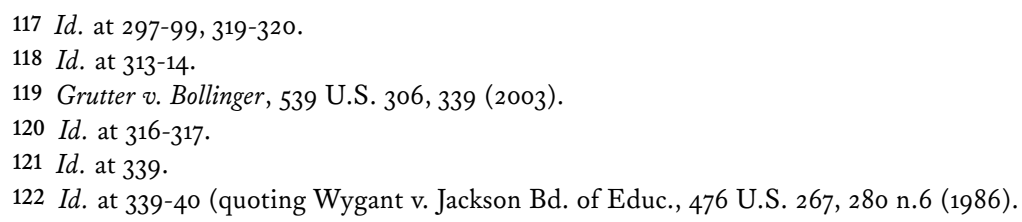


absolutely necessary. In Fisher, the white plaintiff alleged that the University of Texas' affirmative action policy violated the Fourteenth Amendment by considering race in its admissions process and rejecting the plaintiff's application. ${ }^{123}$ While the Court ultimately upheld the affirmative action plan, it modified the "race-neutral alternative" test put forth in Grutter by asserting that "the court must ultimately be satisfied that no workable race-neutral alternatives would produce the educational benefits of diversity. If 'a nonracial approach' ... could promote the substantial interest about as well and at tolerable administrative expense,' then the university may not consider race."124 The Court, therefore, emphasized that race-conscious affirmative action must be, in some sense, a last resort. In an ideal world, the Court implied, white applicants should not be burdened by schools' attempts to diversify their campuses. In this shift, the Court further implicitly underscored its commitment to ensuring that white students' interests and desires are protected and considered before any affirmative action is undertaken. And while the ultimate burden, according to the Court, remains with the plaintiff to show the presence of workable alternatives, the Court nevertheless maintained that the school bore the burden of demonstrating that race-neutral alternatives were insufficient to achieve their goals. ${ }^{125}$

Most recently, the "race-neutral alternative" test has persisted at the appellate court level, with the First Circuit implementing this test in its review of Harvard College's affirmative action plan - which, ironically, Justice Powell referenced in Bakke as an example of a lawful affirmative action initiative.126 In Students for Fair Admissions, Inc. v. President and Fellows of Harvard College, nonprofit Students for Fair Admissions, Inc. alleged that Harvard College's undergraduate affirmative action plan discriminated against Asian American applicants by considering race in its admissions system. ${ }^{127}$ After considering a substantial amount of evidence from Harvard,

123 Fisher v. Univ. of Tex. at Austin, 570 U.S. 297, 306 (2013).

124 Id. at 312 (quoting Wygant 476 U.S. at 280 n.6) (emphasis added).

125 Id.

126 Justice Powell noted:

[Harvard's] program treats each applicant as an individual in the admissions process. The applicant who loses out on the last available seat to another candidate receiving a 'plus' on the basis of ethnic background will not have been foreclosed from all consideration for that seat simply because he was not the right color or had the wrong surname .... His qualifications would have been weighed fairly and competitively ....

Regents of Univ. of Cal. v. Bakke, 438 U.S. 265, 318 (1978).

127 Students for Fair Admissions, Inc. v. President and Fellows of Harvard Coll., 397 F. Supp. 3d 126, 131-32 (D. Mass. 2019), aff'd by 980 F.3d 157 (1st Cir. 2020). In February 2021, the plaintiffs petitioned for a writ of certiorari with the United States Supreme Court. Students for Fair Admissions, Inc. v. President \& Fellows of Harvard College, SCOTUSBLOG, https://www.scotusblog.com/case- 
the court underscored that "if 'a nonracial approach ... could promote the [school's] substantial interest [in diversity] about as well and at tolerable administrative expense," the school would be prohibited from considering race in its admissions procedures. ${ }^{128}$ This standard, however, is less than clear, raising the questions of (1) what it means for an admissions plan to work "about as well" as a race-conscious affirmative action plan; and (2) what constitutes a "tolerable administrative expense."

The court did not address either of these questions explicitly; rather, the court simply noted that alternatives such as eliminating early action and strengthening recruitment efforts "are all 'available' and 'workable' in some form and at varying costs, but they would likely have no meaningful impact on racial diversity." 129 In effect, this standard appears to heighten the burden on schools even further than that in Fisher, regardless of the court's intention.

While the general trend has been for courts to uphold schools' affirmative action policies, there is a clear reliance on the "race-neutral alternative" test that originated in Grutter. There is therefore a clear connecting line between the white centering which occurred in Bakke and more recent affirmative action cases. While Bakke never used the language of "race-neutral alternative" or required their consideration, it laid critical groundwork for this test by dwelling on the ways the school's affirmative action plan operated to the detriment of students like Bakke, rather than dwelling more extensively on the potential benefits such a program could present to non-white and disadvantaged students.

\section{RACE-NEUtRAl Alternatives CENTER White INTERESTS AT THE EXPENSE OF NON-WHITE STUDENTS}

Existing jurisprudence on affirmative action policies, as previously discussed, emphasizes that schools must determine that no workable raceneutral alternative exists prior to launching a race-based affirmative action program. Put differently, the Supreme Court requires schools to first protect white applicants' interests in admission and only consider race if absolutely necessary. But what do schools interested in diversifying their campuses and reversing past harm lose in this standard? And how does the race-neutral alternative test run counter to the original spirit of the Fourteenth Amendment and the Civil Rights Act? By requiring that schools first prioritize the interests of white students in any attempt to diversify their campuses, the Court entrenched the presumption of white "innocence"

files/cases/students-for-fair-admissions-inc-v-president-fellows-of-harvard-college/ [https://perma.cc/ $\left.\mathrm{U}_{5} \mathrm{~K}_{2}-\mathrm{G} 625\right]$.

128 Students for Fair Admissions, 397 F. Supp. 3d at 199-200 (quoting Fisher, 570 U.S. at 312).

$129 \mathrm{Id}$. at 200. 
wherein beneficiaries of race-based affirmative action wrongly obtain an education which, by default, should belong to white students.130

As affirmative action has attracted increasingly negative public attention over the years, and with the Court's race-neutral alternative litmus test, social scientists and other interested parties have sought to introduce methods of diversifying schools that do not consider applicants' race. Proponents of raceneutral affirmative action plans assert that campus diversity may be obtained by using factors which often act as proxies to race and ethnicity, such as socioeconomic status. The most commonly discussed alternatives include income- and geography-based affirmative action. ${ }^{131}$

Proponents of such alternatives argue, among other things, that raceconscious affirmative action "set[s] up minority students for failure" by admitting students who are "underqualified" for the institutions in question. 132 Others argue that race-conscious affirmative action amounts to "gross unfairness" by assisting students who "have never been subject to any significant amount of racial animus." 133 Still others contend that, while race is often correlated with class, race-based affirmative action may nevertheless fail to address the lack of socioeconomic diversity within institutions of higher education. ${ }^{134}$

The proponents of class-based affirmative action have proposed numerous variations which purport to mimic the diversity benefits of race-conscious affirmative action. The most selective high schools in the Chicago Public School system sought to achieve diversity through a class-based affirmative action plan wherein certain Chicago neighborhoods were assigned to one of

130 For a more in-depth discussion on the language of whiteness, see David Simson, Whiteness as Innocence, 96 DENV. L. REV. 635 (2019) (providing a more in-depth discussion of the language of innocence).

131 See generally, Richard Rothstein, Should Race-Based Affirmative Action be Replaced by RaceNeutral Preferences for Low-Income Students? The Discussion Continues, ECONOMIC POL'Y INST. (Aug. 4, 2014, 11:43 AM), https://www.epi.org/blog/race-based-affirmative-action-replaced-race/ [https://perma.cc/DA7U-HYEC] (discussing the merits and pitfalls of income-based affirmative action); SigAl AlON, RACE, ClASS, AND AFFIRMATIVE ACTION 11 (2015) (discussing class-based affirmative action); Sheryll Cashin, Place, Not Race: Affirmative Action and the Geography of Educational Opportunity, 47 UNIV. MICH. J.L. REFORM 935, 936 (2014) (arguing for a geographybased affirmative action scheme in which "use of place, rather than race, in diversity programming will better approximate the structural disadvantages many children of color actually endure"); Fisher, 570 U.S. at 305 (discussing Texas' Top Ten Percent Plan, which granted automatic admission to Texas public universities for students in the top ten percent of all Texas high schools).

132 ALON, supra note 131, at 80.

133 Courtney Rozen, How Americans Feel About Affirmative Action in Higher Education, NPR (Nov. 1, 2018, 9:37 AM), npr.org/2018/11/01/658960740/how-americans-feel-about-affirmativeaction-in-higher-education [https://perma.cc/PP5A-3DM5].

134 Rachel Lu, Two Scholars Debate Race-Versus Class-Based Affirmative Action, THE MIDDLEBURY CAMPUS (Dec. 5, 2019), https://middleburycampus.com/47695/news/two-scholarsdebate-race-versus-class-based-affirmative-action/ [https://perma.cc/UAgA-LFCW]. 
four categories using an index combining median family income, adult education, home ownership, frequency of single-parent households, and nonEnglish speakers as delineators. ${ }^{135}$ In that plan, schools filled $40 \%$ of their classes with applicants with the highest standardized test scores and the remaining $60 \%$ of slots using the tiered socioeconomic system by allocating slots equally between the four tiers. ${ }^{136}$ In subsequent years, the school altered this system to reserve $70 \%$ of slots for admission based on the socioeconomic tiers. 137

In a somewhat less sophisticated approach, the Texas Top Ten Percent plan granted in-state high school seniors in the top ten percent of their graduating classes automatic admission to any Texas public university. ${ }^{138}$ Over the past two decades, schools in California and Florida have implemented similar systems wherein high school students falling in the top four and twenty percent of their graduating classes, respectively, are granted automatic admission into one state university (although this might not be the school of the student's choosing).139 Other schools have eschewed formal admissions policies in favor of targeted recruitment strategies which aim to attract greater numbers of applicants hailing from underrepresented minority backgrounds. For example, some schools have provided more robust scholarship opportunities to offset the cost of attendance for minority students, such as the University of Texas' Longhorn Opportunity Scholarship which is offered to applicants hailing from schools that serve largely underrepresented minority students. ${ }^{140}$

To date, many studies have found that race-neutral alternatives typically fall short of providing the same benefits as race-based affirmative action plans, indicating that the courts' requirement that no workable race-neutral alternative exist prior to starting race-based admissions policies is an unrealistic standard. At best, race-neutral alternatives to affirmative action that seek to act as proxies for race still fail to achieve similar levels of diversity in classes of admitted students. Glenn Ellison and Parag Pathak's 2016 study of selective Chicago public schools found that even the closest proxies for race, such as income, might still fail to satisfactorily increase enrollment of

135 Glenn Ellison \& Parag A. Pathak, The Efficiency of Race-Neutral Alternatives to Race-Based Affirmative Action: Evidence from Chicago's Exam Schools 2 (Nat'l Bureau of Econ. Rsch., Working Paper No. 22589, 2016).

136 Id. at $2-3$.

$137 \mathrm{Id}$. at 3 .

138 Fisher v. Univ. of Tex. at Austin, 570 U.S. 297, 305 (2013).

139 Marvin Lim, Percent Plans: A "Workable, Race-Neutral Alternative" to Affirmative Action?, 39 J. COLL. \& U. L. 127, 128-129 (2013).

140 Morning Edition, Alternatives Emerge to Affirmative Action, NPR (Apr. 25, 2014, 5:03 AM), https://www.npr.org/2014/04/25/306718048/alternatives-emerge-to-affirmative-action [https://perma.cc/ETH4-CRLZ]. 
students from underrepresented minority backgrounds-the study determined that socioeconomic factors used as proxies were still less effective than simply considering applicants' race. ${ }^{141}$ Mark Long, after theorizing that the Texas Top Ten Percent plan was limited in its ability to predict applicants' race for diversity purposes, found that a completely race-neutral system would admit $3.3 \%$ fewer non-white students than a race-based affirmative action plan. ${ }^{142}$

Others have argued that race-based affirmative action plans "minimiz[e] the costs of affirmative action to the institution, by reducing the predicted performance gap between affirmative action students and the rest of the student body and by minimizing the reputational costs to the school that flow from less competitive admissions standards." 143 Maria Cancian theorized that, in fact, many otherwise eligible students from underrepresented backgrounds would be ineligible for class-based affirmative action despite proponents' arguments that class stands in as a surefire proxy for race. ${ }^{144}$ Cancian has also underscored the difficulty of creating thresholds for socioeconomic class in the first instance, a statement supported by many others. ${ }^{145}$

Nevertheless, some researchers have argued that race-neutral alternatives such as class-based affirmative action do succeed in diversifying college classrooms. Matthew Gaertner and Melissa Hart argued that an increase in admissions rates for socioeconomically disadvantaged students at the University of Colorado indicate that class-based affirmative action does work and should be implemented as a strategy which circumvents the use of racial classification. ${ }^{146}$ This finding, however, is clearly in the minority.

While much research remains to be completed, current evidence appears to weigh in favor of race-based affirmative action as a means of achieving racial diversity in U.S. colleges and universities. Class-based and other raceneutral affirmative action alternatives work to assure white Americans that they will not need to bear the burden of policies which seek to address

141 Ellison \& Pathak, supra note 135, at 6 ("[T]he CPS policy is much less efficient when one tries to use it to keep minority representation anywhere close to its former level.").

142 Mark C. Long, Is There a "Workable" Race-Neutral Alternative to Affirmative Action in College Admissions?, 34 J. POL'Y ANALYSIS \& MGMT. 162, 178 (2015) (observing that a school with traditional affirmative action plan had an admitted class of which $19.5 \%$ identified as underrepresented minorities, while a school banning such policies admitted a class wherein $16.2 \%$ of students identified as under-represented minorities).

143 Deborah C. Malamud, Assessing Class-Based Affirmative Action, 47 J. LEGAL EdUC. 452, 455 (1997).

144 Maria Cancian, Race-Based Versus Class-Based Affirmative Action in College Admissions, $17 \mathrm{~J}$. POL'Y ANALYSIS \& MGMT. 94, 102 (1998) ("The simulation results . . suggest that many minority youths will not be eligible for class-based affirmative action.").

145 Id. at 103 ("In contemporary America there is no consensus on the boundaries or even the relevance of the concept of socioeconomic 'class." (citing grusky and Malamud).

146 Matthew N. Gaertner \& Melissa Hart, Considering Class: College Access and Diversity, 7 HARV. L \& POL'Y REV. 367, 367-68 (2013). 
systemic educational disparities in light of centuries of racial oppression but contribute little to racial educational equity. Courts' insistence on this standard reflects their continued centering of white interests. By relying on a standard that simultaneously protects white interests and presents disadvantageous outcomes for non-white students, courts engage in white centering even if they ultimately uphold race-conscious affirmative action policies.

\section{CONCLUSION}

The jurisprudence on affirmative action demonstrates that federal courts, particularly the Supreme Court, have both explicitly and implicitly enforced a standard that both centers white interests and espouses the idea that white individuals should not be forced to bear burdens associated with remedying America's history of racial oppression. Courts' discussion of white "innocence," positing that such "innocent" individuals should not be penalized for past wrongdoing, perpetuates a too broad and non-nuanced understanding of systemic racism and marginalization which hinders meaningful change within the context of higher education. Moreover, adopting a "race-neutral alternative" standard creates the false perception that racial harm can and should be achieved through "painless" mechanisms-that justice can be obtained by still retaining structures that prioritize whiteness. As the findings above demonstrate, if schools truly desire to create more equitable and diverse environments, they must be permitted to consider race when forming admissions policies. As Justice Marshall lamented in his Bakke dissenting opinion, an understanding of the Fourteenth Amendment and the Civil Rights Act which protects white interests tears down remedial efforts with the same language once used to pursue justice for members of marginalized communities. ${ }^{147}$

Rather than requiring schools to comport with a standard which centers white interests to the detriment of historically marginalized minorities, courts should interpret the Fourteenth Amendment and the Civil Rights Act as documents which first and foremost protect minority individuals and efforts to remedy the effects of discrimination against such groups. Moreover, certain racial classifications can indeed be benign-for instance, when a school hopes to increase the enrollment of Black, Latinx, and Indigenous students on their campuses. Rather than continually focusing its analysis on the potential harms a race-based affirmative action plan could cause to white

147 Bakke, 438 U.S. at 387 (Marshall, J., dissenting) ("Now, when a State acts to remedy the effects of that legacy of discrimination, I cannot believe that this same Constitution stands as a barrier."). 
students, the Court should shift its discussion to more heavily consider the potential benefits of an affirmative action plan. To be clear, courts have included discussions of the benefits of race-conscious affirmative action policies to varying degrees over the years. ${ }^{148}$ However, as previously discussed in their analysis, courts have either considered white interests as comparable or superior to those of people of color. This Comment urges courts to consider the ways in which white interests have been held as paramount throughout the history of affirmative action. Only when courts acknowledge this reality will they recognize that their current approaches to affirmative action should draw on the true legislative and social histories of the Fourteenth Amendment and Civil Rights Act of 1964.

148 See, e.g., Fisher, $136 \mathrm{~S}$. Ct. at 2210-11 (noting the benefits of a diverse student body, and that these may be achieved through intentionally increasing the presence of minority students on campus); Grutter, 539 U.S. at 328-30 (agreeing that the law school's attempts to achieve a "critical mass" of minority students confers benefits such as "cross-racial understanding"). 
